\title{
Hizb ut-Tahrir: Dreaming of Caliphate
}

\author{
Meerim Aitkulova
}

\section{Introduction}

Against the background of turmoil in Muslim majority countries that began with escalation of the Palestine and Israel conflict, and the processes of the decolonization and internal collisions between Arabic states, the appearance of Islamic movement like Hizb ut-Tahrir (Party of Liberation) struggling for own version of justice was not unexpected. ${ }^{1}$ However, in a world where the conjunction of religion and politics was long ago dismissed as regressive, the ideas of a new movement claiming to be a political party, but obstinately fighting for an Islamic Caliphate on the Prophet's model, was definitely unusual. The Party persistently spreads this message among Muslims on the global level, while rejecting cooperation with other Islamic movements, and perhaps has never been so popular as it is now. It is the particular focus of close attention by security services and social and political institutions in Central Asia, where Hizb ut-Tahrir attained wide popularity since the collapse of the Soviet system. Yet, Hizb ut-Tahrir gained less international attention than other fundamentalist Islamic movements and often research on this Party is rather controversial, oscillating between labelling it as a 'terrorist' or a 'peaceful' group. In this regard, this chapter attempts to provide more insights into the history and ideology of Hizb ut-Tahrir and the position it takes on violence.

\section{Hizb ut-Tahir: Historical Background}

Hizb ut-Tahrir (Party of Liberation) was founded in 1953 as an Islamic political organization in Jerusalem by an Islamic scholar of Palestinian origin, Taqī al-Dīn al-Nabhānī (19o9-1977). He received his education at several prestigious Islamic institutions including the prominent Al-Azhar University in Egypt. Upon completion of his university studies, he began his career as a

1 An earlier version of this research was published as: M. Aitkulova, 2017, "Hizb Ut-Tahrir: Dreaming of Caliphate," Alternative Spirituality and Religion Review, 8:1, 95-106. This chapter has been revised and updated. 
teacher and later as an appeals court judge in Palestine. The historical background of Hizb ut-Tahrir's appearance is in many ways related to the situation in the "Muslim countries" (al-Nabhani, 1998: 240) in the middle of the twentieth century. Deeply disturbed by the occupation of Palestine, the 1948 Arab-Israeli war, and the collapse of the Ottoman Caliphate in 1914, al-Nabhānī enters the political arena with a new program, generated primarily as a reaction to these factors (Wali 2017: 102). Reflection on the broader question of what happened to the Islamic world that until recently shone in all its might and ruled half of the world, led him to the idea that only the revival of the single pan-Islamic state (Caliphate) could eliminate disunity among Muslims and restore the former glory (Azad 2017: 7). It is worth noting that throughout Islamic history the political component was an inseparable part of Islamic religion, and this complementarity largely influenced on the ideology of many intellectuals since the twentieth century, who also searched for appropriate answers and reactions towards challenges of the post-colonial world. Other influential movements like the Muslim Brotherhood in Egypt (established in 1928), and Jamaat-e-Islami in India (established in 1941), also claimed the right to be present in the political arena in the name of Islam, and campaigned for the reestablishment of an Islamic state (Nuruddin 2017: 276).

The activity of the Muslim Brotherhood in Egypt was a source of inspiration during the early years of al-Nabhānī's career, when he began to explore the opinion that West threatened not only the physical borders of the Muslim majority countries, but also the spiritual and intellectual development of Muslims (Nuruddin 2017: 276). However, al-Nabhānī's disagreement over the proper way to reestablish the Caliphate and his vision of the future of this system resulted in an ideological split with the leaders of Muslim Brotherhood like Hasan al-Banna (1906-1949) and Sayyid Qutb (19o6-1966). Al-Nabhānī criticised them for being too moderate and deviating from the model of the state that was already present in its complete form during the lifetime of the Prophet and Caliphs (Nuruddin 2017: 277).

Unlike some other Islamic religious groups, Hizb ut-Tahrir is well structured and its ideology is clearly defined. This ideology promotes the revival of Islamic umma (community of believers) through the creation of a Caliphate, similar to the one that existed during the era of the Prophet Muhammad and his first four successors (the four 'rightly guided caliphs'). The Party sees the flaws of other Islamic movements in their lack of a strong political program and cooperation with secularists and proclaims itself not as a purely religious organization but rather as a political movement which gets its inspiration from Islam (Taji-Farouki 2000: 22). Therefore, it opposes any other ideologies-whether they be communism, capitalism, or anything else-as alien to Islam. 
For Hizb ut-Tahrir Islam is a self-sufficient totality revealed by God and cannot comply with any humanly created ideologies (Taji-Farouki 200o: 22-23). The main principles of Hizb ut-Tahrir have not changed since the day of its foundation and, despite frequent changes of leadership and changing conditions in the contemporary world, al-Nabhāni’s initial ideas constitute the immutable ground of Hizb ut-Tahrir and continue to inspire many Muslims today. The name of the Party reflects its primary aim of liberating Muslim countries from the influence of the systems of the kufr (non-believers) (Hizb ut-Tahrir n.d. b).

Muhammad Iqbal and Zulkifli Zulkifli (2016: 39) consider Hizb ut-Tahrir as a group that has all the characteristics of the fundamentalist movement, though it is often inaccurately confused with a 'terrorist' group. They define Islamic fundamentalist movements as groups that view themselves as both religious and political movements, believing in the coherence of Islam as an alternative to Western domination, and considering jih $\bar{a} d$ as a necessary element in defending and expanding the Muslim umma, though varied groups may interpret jihād differently.

Today, Hizb ut-Tahrir is one of the largest Islamic movements in the world (Stuart and Ahmed 2010: 143). From its humble beginning in Palestine, the ideas of Hizb ut-Tahrir swiftly spread throughout many countries, largely thanks to the strategy of al-Nabhānī who encouraged his followers to travel extensively, his own charismatic personality and his welcoming approach to all Muslims regardless of race, gender or the madhhab (school of thought) to which they belonged (Osman 2012: 9o). Also, Hizb ut-Tahrir actively disseminates its ideas through leaflets, booklets, lectures, and regular meetings. Today, its media branch is perhaps the most organised and modern, when compared with the media outlets of other Islamic organizations (Iqbal and Zulkifli 2016: 49-50). During the first decade of its activity, Hizb ut-Tahrir experienced relative success in many Arab countries, and had official premises in those countries until it was outlawed after being involved in two coup attempts in Amman, and for fomenting coup plans in number of other Arab countries (Taji-Farouki 2000: 22). It is known that military elements in Jordan, Syria and Egypt closely cooperated with Hizb ut-Tahrir during the coup planning, and it was not until 1977- with the launch of more repressive measures against the Party - that Hizb ut-Tahrir members started to emigrate to the United States, the United Kingdom, Australia, and following the Cold War, to Central Asia, the Caucasus and Southeast Asia (Wibisono 2018).

After the death of al-Nabhānī in 1977, Sheikh Abdul Qaleem Zalloum (19242003) took over the leadership of the Party. It was during his tenure that Hizb ut-Tahrir expanded beyond the limits of its early geographical presence and 
could claim with confidence that it was a truly international organization. However, this expansion was less the result of a conscious strategy and more the result of coercion, as mass persecution and growing resentment in the countries with the greatest numbers of Hizb ut-Tahrir's members forced them to migrate, predominantly to the US and to European countries (International Crisis Group 2003: ii). Later, the processes of globalization in combination with Hizb ut-Tahrir's media strategies, facilitated the internationalization of this organization (Iqbal and Zulkifli 2016:49-50). Currently it is present either officially or clandestinely in more than forty countries (Hasan 2017). Effective use of media potential is one of the distinguishing characteristics of the movement; it adapts the latest modes of communication, through professionally composed printed and media brochures, official and unofficial pages in social media, web sites in the countries where it is present. For example, for a long time, Hizb ut-Tahrir's Central Asian office had pages on the online social media, until they were blocked by security agencies. However, the flexibility of social media allows them to continue own activity under different names and they are easily recognizable due to the specific vocabulary used (terms like 'revival of Caliphate', 'the hypocrisy of the system of the kufr' and so on).

Since it is not easy to estimate the number of followers due to its partially underground nature, the Party's regular conferences and meetings may give some indication of the level of support. For example, the largest Hizb ut-Tahrir conference took place in 2007 in Jakarta (Indonesia), and brought together something like eighty thousand people (Reuters 2007). According to other estimates there were from ten thousand (Filiu 2008) to one million people involved (Dyett 2014); yet this diverse assessment of attendance reflects the fact that it is extremely difficult to provide even rough estimates of their membership and supporters.

It is important to mention Hizb ut-Tahrir's activity in Central Asia (Kyrgyzstan, Kazakhstan, Turkmenistan, Uzbekistan, Tajikistan), where the Party is widely present today, albeit clandestinely (Baran 2004: 2). Following the downfall of the Soviet regime in 1991, Islam, a dominant religion in Central Asian countries, returned in all its diversity of traditions, virtues and new challenges, after being excluded from public sphere by the communist ideology of the Soviet Union. The opening up of society allowed the entrance of many religious movements, including Hizb ut-Tahrir, that swiftly found new members in fertile soil. In the political arena, the Party's enthusiastic activity is usually considered as being more a response to repressive and corrupt regimes in this region, while, from a spiritual point of view, the Party was attractive to the masses, as it could effectively fill the ideological vacuum created by the collapse of the Soviet system (Khamidov 2003: 11). Emmanuel Karagiannis writes 
that today "Hizb ut-Tahrir is among the most feared Islamic groups in Central Asia, but it is also, apparently, the least understood" (2005: 137). Central Asian regimes have a pronounced authoritarian character and tend to be more intolerant toward any movements that could undermine the existing status quo (Heathershaw and Montgomery 2014: 7). Thus Hizb ut-Tahrir's calls for change in the political order - said to be inspired by God himself-have triggered an uncompromising struggle against them. The position of the Central Asian population does not differ much; it is secular in the main, with citizens finding religion a relic of the past that hinders progress. People are skeptical towards any and all religious groups. There are no official statements or statistics about the Party's engagement in acts of violence (Frances 2015), and accusations are mainly based on the presumption that Hizb ut-Tahrir members can be "a conveyor belt" to terrorism (Baran 2004: 11) and their ideology "sanctions military coups and the mass killings of innocent peoples" (Stuart and Ahmed 2010: 143). Yet, their activity attracts attention regarding the question of proportionality of measures against them taken by the authorities. Evidence of brutal persecution, like torture unto death and long term imprisonments for disseminating Hizb ut-Tahrir's literature, on the one hand confer to Hizb ut-Tahrir's members status of innocent victims of the regime (Karagiannis and McCauley 2006:321), while from the human rights perspective the uncompromised struggle against non-violent Party members has come to demonstrate the repressive nature of Russia and the Central Asian states (Human Rights Watch 2017). Today, the Party is banned in all Central Asian countries, in some Middle Eastern countries, in Russia and Germany, and since 2017 in Indonesia (Al Jazeera 2017). Many Hizb ut-Tahrir members have found asylum in European countries, where they regularly conduct demonstrations and conferences against the authorities of their home countries and actively deploy their self-image as victims.

\section{Aim and Ideology}

Let there be among you a group that invites to the good, orders what is right and forbids what is evil, and they are those who are successful.

Qurān 3:104

According to al-Nabhānī's interpretation, Islam is a complete and coherent system of thought that can regulate all aspects of life (al-Nabhani cited in Azad 2017: 70). According to Hizb ut-Tahrir's official website: 
Its aim is to resume the Islamic way of life and to convey the Islamic $d a^{3}$ wah [preaching] to the world. This objective means bringing Muslims back to living an Islamic way of life in Dar al-Islam [Land of Islam] and in an Islamic society such that all of life's affairs in society are administered according to the Shariah [law] rules, and the viewpoint in it is the halal and the haram under the shade of the Islamic State, which is the Khilafah State [Caliphate]. That state is the one in which Muslims appoint a Khaleefah [Caliph] and give him the bay'ah [an oath of allegiance to a leader] to listen and obey on condition that he rules according to the Book of Allāh (swt) and the Sunnah of the Messenger of Allāh (saw) and on condition that he conveys Islam as a message to the world through da'wah and jihäd.

HIZB UT-TAHRIR n.d. a

This aim embodies, in brief, the core idea of Hizb ut-Tahrir; all other documents and programs processed by the Party are issued in accordance with the main points of this central aim.

Being revealed by God, Islam is the only true way of life and all sovereignty in this system belongs to God, not humankind. Its political ideology encompasses two principles: sharîa or Islamic law, needed for the foundation and operation of a just society; and second, the Islamic state or Caliphate that can ensure and protect shari $a$. Therefore, all-regulative character of Islam is only possible within the Caliphate system, where faith (din) and state (dawla) are inseparable (Hizb ut-Tahrir n.d. a). In upholding its ideology, the Party refers to the historical Caliphates, when this system of governance granted stability for the Muslim people and independence from other countries. Al-Nabhānī writes of the Islamic state that "it is not a dream, nor is it a figment of the imagination, for it had dominated and influenced history for more than thirteen hundred years" (cited in Azad 2017: 70). Al-Nabhānī expected that at first the Caliphate or Islamic state would be established in one of the Arabic-speaking countries and would eventually encompass all Islamic countries. However, his ideas later proved to be more popular in other places.

Al-Nabhānī synthesised classical Islam with modern politics, which resulted in a draft constitution (1953) of the future Caliphate that contains a code of laws for the political, economic and social system of the state and its foreign policy (Stuart and Ahmed 2009: 17). According to the constitution, the head of the state, the Caliph, is an elected figure and should be just and accountable leader, as he is a symbol of the God's absolute power and his representative on earth (Draft Constitution of the Khilafah State 2011: Article 34). The 
constitution stipulates that the state will be governed by shari $a$ law and that people of the book (Christians and Jews) will be allowed to practice their religion freely by paying jizya (a special tax, historically levelled on Christians and Jews), while other faiths will not be tolerated until they convert to an acceptable religion within the Caliphate (al-Nabhani 1997: 228).

Unlike other Islamic parties, Hizb ut-Tahrir has a comprehensive constitution encompassing ready-to-implement policies for every sphere of life. While there is some slight accommodation to modern realities, all of al-Nabhānī's views on the Islamic state are available in the official documents of the Party and are actively distributed by its members. The Party, although espousing the uncompromised pursuit of the Prophet's model of life and governance, is unable to replicate this in its 'purest form' and faces some paradoxes in its activities. The constitution, although tailored for the Caliphate system, takes a lot from the Western systems of law and governance; also many Party members found asylum in Western kufr countries, ${ }^{2}$ and in Indonesia the democratic climate allowed the Party to flourish and conduct large demonstrations, despite the stark criticism of Indonesia's democratic model by Hizb ut-Tahrir.

Despite his zeal for the idea of the Caliphate, al-Nabhānī was no less realistic and expected many obstacles on the way, like the influence of the colonial legacy on economy, culture and politics in majority Islamic countries that might participate in the future Caliphate. In the modern stage of the Party's development, the idea of Caliphate appears more like a dream, one that might never come true, but will be an eternal source of inspiration. According to Iqbal and Zulkifli, today Party members "are not interested in discussing the details of the proposed Islamic Caliphate ... more important for them here is a psychological need to believe that great Islamic Caliphate will emerge as inescapable entity to bring back the Muslim glory" (2016: 56). Sabara Nuruddin (2017: 277) also has an impression that "HT is a model of romantic political consciousness that idealises the past for the future." In addition, many authors find the re-establishing of the Prophet's model of the Caliphate as utopian, unless the blueprint model is adapted for modernity, which would be a major deviation from the Party's position (Nuruddin 2017: 283).

The Party makes many statements on the governmental system of democracy. While acknowledging many commonalities between Islam and democracy, the Party nevertheless finds them incompatible on the matter

2 Although Party justifies this based on the story of migration of the Prophet Muhammad from Mecca to Medina, where he and his followers found refuge and welcoming approach from Jewish and pagan Arab tribes, most of whom later converted to Islam. 
of sovereignty (Baran 2004: 18), and on the basis that democracy was largely developed in the kufr lands. The supreme role of the demos (people) in a democratic state is not acceptable for the Islamic state as envisaged by Hizb utTahrir, where God is the only source of governance and the people are those who submit to his power (Azad 2017:9). All other states where governance is not based on this principle - that is, the primacy of God-live in the state of jāhiliyya (ignorance) (Azad 2017: 9). Therefore, the Party rejects democracy and other political ideologies as being man-made, and thus un-Islamic and inherently flawed. Due to this basic contradiction, Hizb ut-Tahrir believes that "we are already in an ideological clash between the secular democratic ideology and the God-given system" (Robin interview by Baran 2004: 18). Moreover, the Party has a divine duty to bring people to the correct path, that of Islam, since with the downfall of the last Caliphate, all Muslims are in a state of jähiliyya and, by living under Western-composed concepts, their situation is only worsening. Even Islamic states like Saudi Arabia and Iran are dismissed as non-Islamic for their policy of double standards and for sharing the ideologies of the kufr (Iqbal and Zulkifli 2016: 51). On this point, the Party refers to pre-Islamic history when Arabic tribes lived in similar state of ignorance and polytheism until the Prophet Muhammad introduced the only true religion of Islam. According to the Party, in the new world order-by God's mercyland, resources, and power to regulate them within the limits set by God, will be given to the people and all merits will be equally shared (Stuart and Ahmed 2009: 17).

Born in the era of upheaval in the Muslim world, Hizb ut-Tahrir from the very beginning has yearned for justice and is actively propagating this notion today to resist the era of neo-colonialism and capitalism. Anti-Zionism and anti-Western rhetoric are particularly strong in the Party's propaganda. Hasan Azad finds Hizb ut-Tahrir's ideology in comparison with other radical Islamic movements "as a clear (some say radical) alternative to Western modes of being and thinking, upholding (and preaching) a clear message of political, epistemological, and religious-ethical unity in the face of an overweening West" (2017: 16). Suha Taji-Farouki notes that this animosity is largely based on the conspiracy theories shared by Party members since they strongly believe that "Jewish and Christian unbelievers allegedly form a united front against Muslims, and are engaged in a permanent effort to destroy Islam: haunted by echoes of the historical cry of 'Allāhu Akbar' at the Gates of Vienna, they are terrified at the mere prospect of an Islamic reassertion" (2000: 24).

In recent decades, with the geopolitical problems in the world and the deteriorating situation in Muslim majority countries, the Party's ideals of struggling 
for a just world look increasingly reasonable to many Muslims around the globe. This fosters the Party's zeal to disseminate the divine order. Hizb utTahrir members believe that working for the Party is the same as serving God (Sinclair 2014: 4).

\section{Hizb ut-Tahrir Methodology}

The Party strongly opposes gradual and 'soft' approaches to implementing Islam, as real changes are only possible through uncompromising radical actions; otherwise, it would mean that "Allāh has sent something impractical that has to be made practical by Muslims" (Mayer 2004: 14). Hizb ut-Tahrir often refers to historical events depicting the success of radical changes, like the rise of communism and, more importantly, the life of the Prophet Muhammad, which was full of drastic measures. However, the notion of radicalism in the Party's ideology means achieving radical change within the existing order of the Muslim world without resorting to violence. As of 2017, "the Method" of Hizb ut-Tahrir outlined online included the statement that Party members "consider that Islamic law forbids violence or armed struggle against the regime as a method to reestablish the Islamic State" however the most recent update of this website in 2020 gives some indication of when taking up arms is in the Party's purview, that is, in the case of jihäd, discussed below (Hizb utTahrir n.d. a).

Instead of advocating the forceful seizure of the State, it rather opts for peaceful methods to attract more members. The Party pays keen attention to the education, both religious and secular, as the $d a^{c} w a$ (preaching) and intellectual debates require a sophisticated knowledge to recruit new members on both grassroots and higher levels and get wider outreach (Zahid 2014: 4). Also, Hizb ut-Tahrir finds it important to win over the minds of members of the military, as they are capable of carrying out peaceful coups when the right moment arrives (Zahid 2014: 4). The amalgam of passion for the Caliphate and competence in religious questions makes their ideas highly attractive and distinguishes it from other religious movements criticised for superficial knowledge.

For the Party, Islam as a universal religion is based on proper ideas ( fikra) and methods (tarīqa), and no other inventions are needed to justify this divine combination (al-Nabhani cited in Osman 2012:95). In this regard, the Party is unwilling to cooperate with other Islamic organizations, viewing their errors as misunderstandings of the basic tenets of Islam. Al-Nabhāni emphasised that other parties had unclear ideas that were often influenced by modern 
concepts and undefined methods (Baran 2004: 19). Additionally, members of other parties responsible for change were often disorganised and incoherent in their actions. To resolve these problems, the Party argued that the best approach was demonstrated by the Prophet himself, and during the golden age of Islam under the rule of the four righteous Caliphs. Thus, Hizb ut-Tahrir does not claim originality in its plan of action for Caliphate building. Rather, by adopting the three-staged program of the Prophet Muhammad, the Party anticipates the same divinely-inspired success that was attained more than a thousand years ago (Baran 2004: 20).

\subsection{First Stage: Culturing}

The first stage involves recruiting and developing intellectually candidates "to produce people who believe in the idea and the method of the Party, so that they form the Party group" (Hizb ut-Tahrir n.d. a). Hizb ut-Tahrir reminds its recruits about the patience and individual approach demonstrated by the Prophet during his preaching activities, as well as his tireless efforts to educate his community of believers. After the potential member initially accepts the Party's basic ideas, the process of more nuanced teaching on an individual basis about their ideas and methods begins. According to Baran "by the end of the first stage, the нт member is ideologically, theologically and spiritually prepared to deal with any hardship that may befall him or her by being certain that this is God's path" (2004: 21). This part is considered important for the growth of the group, capable of spreading its ideas to others.

During the first stage potential Party followers get an education in study circles called halaqa that replicates the historical Islamic study method (Azad 2017: 10). The method is still widely used in the Islamic world when students sit in a circle on the floor in the mosque or teacher's home. Halaqas cover different topics related to Islam, moreover, since Islam is considered by members as a complete way of life all other 'non-religious' subjects are also relevant for study. In halaqas followers listen to al-Nabhānīs basic ideas, by reading his main books or listening to the teacher's lections about his ideas. All lectures have a heavy focus on the idea of the revival of the Caliphate infused with the criticism of the modern systems. New recruits in the initial stage of the study are not allowed to question the Party goals and are expected to comprehend the ideas through hard study and practical work (finding new members and practice of Islam) (Azad 2017: 11).

\subsection{Second Stage: Interacting with the Muslim Umma}

At this stage, the Party continues to introduce its ideas to the larger Muslim population so that they implement its ideology in life. It is described as: 
The collective culturing of the masses of the Ummah with the thoughts and the rules of Islam which the Hizb had adopted, through lessons, lectures, and talks in the mosques, centres and common gathering places, and through the press, books and leaflets. This was done in order to create a common awareness within the Ummah and to interact with her.

HIZB UT-TAHRIR n.d. a

Here the Party operates more decisively, and openly propagates ideas that create conflict between the umma and ruling regimes (Khamidov 2005: 7). Again, this is inspired by a key event in Islamic history, when the Prophet Muhammad raised his umma, composed of people from different nations and social classes, to resist the corrupt regime of the Quraysh tribe in Mecca. On the way to uniting all Muslims into single umma, the Party is rather flexible in its approach to other interpretations of Islam practiced by different Muslims.

\subsection{Third Stage: Establishment of the Islamic State}

According to Hizb ut-Tahrir, the final stage will eventually come after the whole umma embraces the Party's ideology (Khamidov 2005: 7). However, the work of the Party does not stop on this stage, because only after the entire world comes under the rule of Islam can the Party claim that its mission is completed. At present, the Party can be considered to be at the second stage (Baran 2004: 21). Initially, al-Nabhānī set an ambitious thirteen-year timeframe for accomplishing these stages, which was later extended to thirty years (International Crisis Group 2003: 3). When this period proved to be unrealistic as well, the Party claimed that it will patiently continue its tireless efforts for the order of God to be established on earth as long as needed (Hizb ut-Tahrir n.d. a).

\section{Attitude to Violence and Jihād}

It is widely reported that Hizb ut-Tahrir rejects violence as a method to achieve its aim, and extensively uses primarily propaganda tools (Khamidov 2005: 4; Karagiannis and McCauley 2006: 315; Stuart and Ahmed 2009: 18). In taking such a position, Hizb ut-Tahrir also regards itself as pursuing the path of the Prophet Muhammad, who "limited his struggle for the establishment of the Islamic State to intellectual and political work. He established this Islamic state without resorting to violence" (Hizb ut-Tahrir Britain 2007), and instead looked for support from other tribes and relied on his followers. Hizb ut-Tahrir adopted such an approach in the concept of nusra, which means looking for

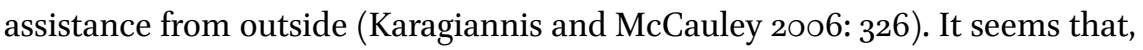


in order to avoid violence, the ideal scenario for the Party would be a peaceful coup d'état undertaken by military forces, that in turn would hand over power to the Party (Karagiannis and McCauley 2006: 326 ). This is why it is so important for Hizb ut-Tahrir to gain the nusra from the military block.

Despite their harsh criticism of US policy in the Middle East, Party members have never been involved in acts of violence (Safi 2015). Acts of terrorism committed by other Islamic groups evoke the Party's official condemnation and serve to accentuate their ideological and methodological distance from such organizations. The Party has argued that jihadist terrorism is counterproductive to their goal. Furthermore, even if conditions were to make jihäd a valid option, the killing of innocent civilians is unacceptable (Hizb ut-Tahrir 2014). For example, in relation to the Caliphate pronounced by IsIs, the Party claimed it to be "islamically illegitimate" (Hizb ut-Tahrir 2014) due to the purely militaristic character of ISIS and a number of other Islamic factors which ISIS violated when established a Caliphate. Regarding Al-Baghdadi's proclamations against the Iraqi government Hizb ut-Tahrir has described his words as "empty speech without substance" (Al Jazeera 2014). Indonesia is an interesting case of the counter terrorist achievements of Hizb ut-Tahrir when some former members of violent Islamic organizations denounced violence and joined the Party (Osman 2012: 98). As a demonstration of its allegiance to non-violent means, the Party often brings up the example of the peaceful resistance of its own members from Central Asia who are under close surveillance from security services and often end up imprisoned or even tortured to death.

However, many experts consider the Party's relation to political violence as more nuanced than it appears at first glance. Emmanuel Karagiannis and Clark McCauley (2006: 328) provide two ways of describing the Party's ideology on violence: "the first is to say that they have been committed to non-violence for fifty years. The second is to say that they have been waiting fifty years for the right moment to begin violent struggle." For Mohamed Osman (2012: 98), "Hizb ut-Tahrir's general non-violent position does not mean that the party is avowedly non-violent at all times."

The Party's envisioning of the concept of jihād may provide more clarity on the question of violence. Jiha $\bar{d}$ in Islam is a complex concept, basically meaning that it is the religious duty of Muslims to struggle in the way of God (Shah 2013: 344). This struggle has two aspects: first, inner struggle against one's own ego, one's harmful desires, and resistance to the temptations that corrupt the soul. In the Islamic tradition, this version of non-violent jiha ad turned inward is often referred to as the greater jiha $\bar{a}$, since mastering the self is considered more difficult than engaging in a physical struggle. The second aspect of jihâd, also referred to as 'lesser jiha $\bar{a} d$ ', is warfare against the enemies of Islam, which 
can take the form of offensive or defensive struggle. Defensive jihād is usually set in motion when Muslim territories are occupied by foreign invaders, while offensive $j i h \bar{a} d$ is warfare launched by Muslims to expand Islamic rule to other territories.

For the Party, it is obligatory for every Muslim to fight if their lands are invaded and occupied, regardless of whether or not the Caliphate has been established (Abedin 2005). As such, for the Party, fighting against foreign occupiers in Palestine, Iraq, and Afghanistan is considered to be defensive jihād. Focusing on this distinction, it can be said that there might exist a fragile border between defensive and offensive $j i h \bar{a} d$, as the first may easily turn into the second under specific social and political circumstances (Ahmed and Stuart 2009: 22).

If the Party resorts primarily to peaceful means for the revival of the Caliphate, then the potentially 'violent' part of jihād may be launched later after the establishment of the Caliphate, since this model of expanding the Caliphate is acceptable in Islam. This model of expanding or offensive $j i h \bar{a} d$ is detailed in the Party's publication, The Inevitability of the Clash of Civilizations (2002), in which, along with calls for the intellectual struggle against Western culture, the Islamic legitimacy of offensive warfare is emphasised as well. The Party argues that the Muslims with their din (faith) and civilization on one side, and Christians with their capitalistic worldview on the other side, were always clashing with each other:

The clash of civilizations as an inevitable matter. It existed in the past, exists now and will remain until the clash ends shortly before the Hour, since it does not come except upon the worst of creation. Do not be deceived, O Muslims, by the callers to the dialogue who place their heads in the sand and condone humiliation and defeat. Make the preparations required for the conflict, since the Capitalist Western civilization has knocked you down militarily, politically and economically.

HIZB UT-TAHRIR 2OO2: 62

Yet, the Party stresses that they cannot legitimately launch an offensive jihäd, as it is the prerogative of the Caliph only (Karagiannis and McCauley 2006: 325). Thus, until his Caliphate is established, the Party continues its intellectual struggle to persuade Muslims and non-Muslims about the righteousness of their aims.

As for criticism of the notion of offensive $j i h \bar{a} d$, the Party responds that it is legitimate for every nation state to declare war under certain conditions (Hizb ut-Tahrir 2002: 25). For example, they state online: 
The fact that the Party does not use material power to defend itself or as a weapon against the rulers is of no relevance to the subject of jihād, because jihād has to continue till the Day of Judgement. So whenever the disbelieving enemies attack an Islamic country it becomes compulsory on its Muslim citizens to repel the enemy. The members of Hizb ut-Tahrir in that country are a part of the Muslims and it is obligatory upon them as it is upon other Muslims, in their capacity as Muslims, to fight the enemy and repel them. Whenever there is a Muslim amir who declares jiha ad to enhance the Word of Allāh $(s w t)$ and mobilises the people to do that, the members of Hizb ut-Tahrir will respond in their capacity as Muslims in the country where the general call to arms was proclaimed.

HIZB UT-TAHRIR n.d. a

The Party also refers to the unlawful acts of the US and the state of Israel against Muslims under the guise of democracy building. Thus the Caliphate as a legitimate Muslim state has even more justification, given that it is concerned with bringing global justice under Islam. In recent times, against the background of the growing religious terrorism in the world and severe persecution of Hizb ut-Tahir members in some countries, the Party's 'classical' perception of violence is being strained. Thus, the official web sites in general try to stand by al-Nabhānī's vision of violence, and official leaders preach divine punishment. However, on the individual level, some voices welcoming violent acts can be traced in the online social media. Some experts also claim that the Party acts as a gateway for jihädi terrorism (Baran 2004: 11; Stuart and Ahmed 2010:143), and that non-involvement in acts of violence does not mean that the Party does not contribute to it through its own ideology that may inspire some 'violent jihadists'.

\section{Structure and Funding}

The structure of the Party is strictly hierarchical and resembles a pyramid with an amir (supreme leader) positioned on the top (Osman 2012: 92). The specific aim of the Party is incompatible with their secular surroundings, and this demands a highly centralised and disciplined structure. The primary leadership centre, located in Arab territory, is primarily concerned with the general coordination of the Party's ideological activities, as well as being responsible for the promotion of the Party's ideas on the higher levels (among politicians and armies for the realising of the so-called nusra concept) (Osman 2012: 92-93). At the next level are committees responsible for the coordination of 
a particular region or country (Baran 2004: 24). For example, the Party has an administrative committee regulating the Central Asian region. However, due to bans on the activity of the Party in that region, the committee's office is located in London. At the lower levels are local committees that oversee cities and the Party's smaller cells (Baran 2004: 24). As noted, the centralised character results in a top down approach when it comes to passing along the Party's documents and directives. According to Taji-Farouki (2014: 46), unlike other revolutionary organizations, Hizb ut-Tahir has managed to maintain this structure since the day of its establishment, and has demonstrated long term ideological cohesion, as well as a lack of serious disagreements and splits in internal structures.

The membership in the Party requires a period of indoctrination that is needed to detect possible security agents and to keep ideological unity. By the end of this intensive period of the study of al-Nabhānī's primary documents, a new member pledges allegiance to the Party's ideals with an oath of loyalty and an agreement to obey orders (Baran 2004: 25). Karagiannis and McCauley (2006: 317) compare the effectiveness of the Party's structure to that of the Bolshevik revolutionaries in Russia, when each level had a clear vision and a task toward attaining an ultimate goal. Depending on the legal status of Hizb ut-Tahrir in different countries - whether it is either recognised or bannedthe Party accordingly acts openly or in a chain of secretive cells. Ironically, the Party, which is so antagonistic towards the Western world and its concepts, has more freedom for its activities in Western countries, but is not tolerated in many Muslim majority countries.

The Party stresses the importance of the role of women. Women in Hizb ut-Tahrir act as main recruiters of other women, as cross gender recruiting is forbidden, and carry out religious education in line with the Party's ideology in female-only cells (Baran 2004: 32). Though it is not easy to give the statistical data on female membership, we can assume significant numbers as male members will try to engage their wives, mothers, or sisters to the new ideology. It can also happen the other way around. Women also actively support the women of an imprisoned member's family (Cragin and Daly 2009: $5^{2}$ ).

Funding mainly comes from the donations of the members, who, depending on their own income, contribute a percentage to the Party, and propaganda activity, being an effective and non-violent tool for raising awareness, is the primary expense (Osman 2012: 99). Donations from wealthy Muslim patrons also constitute an important part of the Party's income. Mutual assistance and support for the families of members who are imprisoned or in need is also a characteristic activity of the Party, and this perhaps is another factor in the popularity of Hizb ut-Tahrir. 


\section{$7 \quad$ Conclusion}

The ideas of Hizb ut-Tahir have stood the test of time and its current transnational character reflects the ideological success of this group. Spreading from the Arab world to America and Asia, it is insensitive to gender, race or madhhab biases, welcoming all who believe in one God and who are ready to share the Party's ideology. The ideas of Caliphate building and the awakening of the whole umma as a single entity seem to have a strong utopian flavour, even after years of the Party's activity. Yet, with al-Qācida and Is Is in the background and growing resentment among contemporary Muslims, the idea of the Caliphate does not seem so fantastic. The Party was able to launch a wide-scale ideological propaganda campaign to win over the hearts and minds of many Muslims. However, despite many accusations of being an inspiration for jihädi terrorism, in its official rhetoric of the Caliphate revival in the current century, the Party continues to adhere to the initial method advocated by its founder al-Nabhānī, who stressed that an Islamic state represents the only safe haven, but the way to that goal should not be paved with blood (at least there is no official information of Party members being involved in violence). Based on the characteristics and the methods of the Party considered in this chapter, it is likely that the movement will continue to expand.

\section{References}

Abedin, M. 2005. "Inside Hizb ut-tahrir: An Interview with Jalaluddin Patel, Leader of Hizb ut-Tahrir in the UK." Spotlight on Terror. 2:8. At https://jamestown.org/inter view/inside-hizb-ut-tahrir-an-interview-with-jalaluddin-patel-leader-of-hizb-ut -tahrir-in-the-uk/. Accessed o1/o7/202O.

Ahmed, H. and H. Stuart. 20o9. Hizb ut-Tahrir: Ideology and Strategy. London: The Centre for Social Cohesion.

Aitkulova, M. 2017. "Hizb Ut-Tahrir: Dreaming of Caliphate." Alternative Spirituality and Religion Review. 8:1, 95-106.

Al Jazeera. 2014. “Islamic State's 'caliph' lauds Iraq rebellion.” Al Jazeera. At https:// www.aljazeera.com/news/middleeast/2014/o7/islamic-state-caliph-lauds-iraq -rebellion-20147512574517772.html. Accessed o1/o7/2020.

Al Jazeera. 2017. "Hizb ut-Tahrir Indonesia banned to 'protect unity'” Al Jazeera. At https://www.aljazeera.com/news/2017/o7/indonesia-hizbut-tahrir-group-banned -protect-unity-170719050345186.html. Accessed o1/o7/2020.

Al-Nabhani, T. 1997. The Economic System of Islam. London: Al-Khilafah Publications. 4 th ed. 
Al-Nabhani, T. 1998. The Islamic State. London: Al-Khilafah Publications.

Azad, H. 2017. (Im)Possible Muslims: Hizb ut-Tahrir, the Islamic State, \& Modern Muslimness. PhD. Columbia University.

Baran, Z. 2004. Hizb ut-Tahrir. Islam's Political Insurgency. Washington DC: The Nixon center.

Cragin, K. and S.A. Daly. 2009. Women as Terrorists: Mothers, Recruiters, and Martyrs. Santa Barbara: ABC-Clio.

Dyett, G. 2014. "Explainer: What is Hizb ut-Tahrir?" SBS News. At https://www.sbs.com .au/news/explainer-what-is-hizb-ut-tahrir. Accessed o1/o7/202O.

Filiu, J-P. 2008. "Hizb ut-Tahrir and the fantasy of the caliphate." Le Monde Diplomatique. At https://mondediplo.com/2008/06/o4caliphate. Accessed o1/o7/202O.

Frances, W.S. 2015. "Why ban Hizb ut-Tahrir? They are not Isis - they're Isis' whipping boys." The Guardian. At https://www.theguardian.com/commentisfree/2015/feb/ 13/why-ban-hizb-ut-tahrir-theyre-not-isis-theyre-isiss-whipping-boys. Accessed o1/07/2020.

Hasan, S. 2017. "The lingering shadow of Hizb ut-Tahrir." TRTWORLD. At https://www .trtworld.com/magazine/the-lingering-shadow-of-hizb-ut-tahrir-10302. Accessed $01 / 07 / 2020$.

Heathershaw, J. and D.W. Montgomery. 2014. The Myth of Post-Soviet Muslim Radicalization in the Central Asian Republics. Chatam House.

Hizb ut-Tahrir. N.d. a Hizb ut-Tahrir. At http://www.hizb-ut-tahrir.org/index.php/EN/ def. Accessed o1/o7/202O.

Hizb ut-Tahrir. N.d. b. The Aim of Hizb ut-Tahrir. At http://www.hizb-ut-tahrir.info/ en/index.php/definition-of-ht/item/7982-the-aim-of-hizb-ut-tahrir. Accessed o1/07/2020.

Hizb ut-Tahrir. 2002. The Inevitability of the Clash of Civilisations (hatmiyyat sira'a Il-hadharat). London: Al-Khilafah Publications.

Hizb ut-Tahrir. 2011. Draft Constitution of the Khilafah State. Article 34. At http:// www.hizb.org.uk/wp-content/uploads/2011/o2/Draft-Constitution.pdf. Accessed 01/07/2O2O.

Hizb ut-Tahrir. 2014. The vicious and wrongful attempts to link Hizb ut-Tahrir to ISIS. At http://www.khilafah.com/the-vicious-and-wrongful-attempts-to-link-hizb-ut -tahrir-to-isis/. Accessed o1/o7/2020.

Hizb ut-Tahrir Britain. 2007. "Report: Iraq a New Way Forward." Hizb ut-Tahrir Britain, 27 March. At http://www.hizb.org.uk/resources/whitepapers/report-iraq-a-new -way-forward/. Accessed 10/o8/2020.

Human Rights Watch. 2017. "Crimea: Persecutions of Crimean Tatars intensifies. Arbitrary detentions: Separatism, terrorism charges." HRW. At https://www.hrw .org/news/2017/11/14/crimea-persecution-crimean-tatars-intensifies. Accessed o1/07/202O. 
International Crisis Group. 2003. Radical Islam in Central Asia: Responding to Hizb utTahrir. Crisis Group.

Iqbal, A.M. and Z. Zulkifli. 2016. "Islamic fundamentalism, nation-state and global citizenship: the case of Hizb ut-Tahrir." Indonesian Journal of Islam and Muslim Societies. 6:1, 35-61.

Karagiannis, E. 2005. "Political Islam and Social Movement Theory: The Case of Hizb ut-Tahrir in Kyrgyzstan.” Religion, State \& Society. 33:2, 137-150.

Karagiannis, E. and C. McCauley. 2006. "Hizb ut-Tahrir al-Islami: Evaluating the threat posed by a radical Islamic group that remains nonviolent." Terrorism and Political Violence. 18:2, 315-334.

Khamidov, A. 2003. Countering the Call: The U.S., Hizb-ut-Tahrir, and religious extremism in Central Asia. Washington: The Saban Center for Middle East Policy at the Brookings Institution.

Khamidov, A. 2005 "Hib-ut-Tahrir: an enduring challenge for Central Asian." AKI Crises Today. 1-20.

Mayer, J-F. 2004. “Hizb ut-Tahrir-The Next al-Qaeda, Really?” PSIO Occasional Paper. $4,1-24$.

Nuruddin, S. 2017. "Hizbut-Tahrir in daw'ah and Islamic political movements in Indonesia." Journal of Islamic Civilization in Southeast Asia. 6:2, 271-294.

Osman, M. 2012. "Hizb ut-Tahrir." In S. Akbarzadeh ed., Routledge Handbook of Political Islam. New York: Routledge, 89-105.

Reuters. 2007. "Muslims meet in Jakarta for pan-Islamic state talks." Reuters. At https:// www.reuters.com/article/us-indonesia-muslim/muslims-meet-in-jakarta-for-pan -islamic-state-talks-idUSJAK28049220070812. Accessed o1/o7/202O.

Safi, M. 2015. "Hizb ut-Tahrir insists it rejects violence following Abbott's 'desperate' accusation.” The Guardian. At https:/www.theguardian.com/australia-news/2015/ feb/2o/hizb-ut-tahrir-insists-it-rejects-violence-following-abbotts-desperate -accusation. Accessed o1/07/2020.

Shah, N.A. 2013. "The use of force under Islamic Law." The European Journal of International Law. 24:1, 343-365.

Sinclair, C. 2014. Whose Caliphate? The Ideology and Geo-Politics of Islamic State. Syddansk: Center for Mellemoststudier.

Stuart, H. and H. Ahmed. 2010 "Profile: Hizb ut-Tahrir in UK." Current Trends in Islamist Ideology. 10, 143-172.

Taji-Farouki, S. 2014. "Hizb ut-Tahrir." In F. Peter and R. Ortega eds, Islamic movements in Europe: Public Religion and Islamophobia in the Modern World. London: I.B. Tauris, 44-5o.

Taji-Farouki, S. 200o. "Islamists and the threat of Jihad: Hizb al-Tahrir and alMuhajiroun on Israel and the Jews." Middle Eastern Studies. 36:4, 21-46. 
Wali, F. 2017. "Functionality of Radicalization: A Case Study of Hizb ut-Tahrir." Journal of Strategic Security. 10:1, 102-117.

Wibisono, A. 2018. "Hizbut Tahrir in Indonesia: Riding the wave of the Islamization Agenda." Middle East Institute. At http://www.mei.edu/content/map/hizbut-tahrir -indonesia-riding-wave-islamization-agenda. Accessed o1/o7/2020.

Zahid, F. 2014. "The Caliphate in South Asia: A Profile of Hizb-ut Tahrir in Pakistan." Terrorism Monitor Volume. 12:14, 4-5. 